Gut, 1979, 20, 1083-1087

\title{
Bile acid clearance in liver disease
}

\author{
K. L. LUEY, ${ }^{1}$ AND K. W. HEATON ${ }^{2}$ \\ From the University Defartment of Medicine, Bristol Royal Infirmary, Bristol
}

SUMMARY The disappearance of intravenously administered cholylglycine- ${ }^{14} \mathrm{C}$ was studied in the fasting and postprandial states in seven subjects with healthy livers and 10 patients with liver disease. In neither group was there any significant difference in the pattern of ${ }^{14} \mathrm{C}$ disappearance. In another 10 patients with liver disease there was no significant change when a loading dose of cholylglycine was given orally two hours beforehand. Clearance of bile acids seems to be unimpaired in all except severe liver disease. The apparent deterioration in endogenous bile acid removal after meals may be due simply to the increased amount of bile acids which are in circulation and available for portosystemic shunting.

Despite theoretical attractions and initially promising reports (Josephson, 1941; LaRusso et al., 1975; Calcraft et al., 1975; Hofmann, 1977), the socalled intravenous bile acid tolerance test, which is normally performed in the fasting state, is now known to discriminate poorly between normal subjects and hepato-biliary disease (Ferguson et al., 1976; Isaacs et al., 1976; Thjodleifsson et al,, 1977; Gilmore and Thompson, 1977). In contrast, several studies have shown that the postprandial serum bile acid concentration, which has been called the endogenous bile acid tolerance test (van Blankenstein et al., 1977), discriminates excellently and does so better than the same measurement in the fasting state (Kaplowitz et al., 1973; Barnes et al., 1975; Fausa and Gjone, 1976; Thjodleifsson et al., 1977), though not all workers agree on this point (Pennington et al., 1977; van Blankenstein et al., 1977). If the postprandial serum concentration is indeed a better discriminator, this may be related to the finding that the serum bile acid concentration rises more after a meal in patients with liver disease than it does in healthy subjects (Fausa, 1976; Osuga et al., 1977; van Blankenstein et al., 1977). These observations imply that the diseased liver removes endogenous bile acids less completely after a meal than in the fasting state. Possible reasons for this are hepatic overload from the increased bile acids in circulation that follow gallbladder contraction, and increased shunting of absorbed bile acids round the liver. If hepatic overload is the correct explanation, the

'Present address: Gastrointestinal Unit, Christchurch Public Hospital, Private Bag, Christchurch, New Zealand.

${ }^{2}$ Requests for reprints should be addressed to $\mathrm{K}$. W. Heaton.

Received for publication 16 July 1979 disappearance of intravenously administered bile acid should, in liver disease but not in health, be slower after a meal and after an artificial load of bile acids than in the fasting state. Furthermore, if clearance were indeed slower in these circumstances, the hope of a sensitive bile acid disappearance test might after all be realised. This study was designed to examine these possibilities.

\section{Methods}

Seven hospital patients with no clinical evidence of liver disease and normal routine liver function tests (Table 1) acted as controls. These and 10 patients with biopsy-proven chronic liver disease (Table 2) were each studied twice-after an overnight fast and, on another day, two hours after the ingestion of a Lundh test meal (Casilan, $150 \mathrm{~g}$; corn oil, $18 \mathrm{~g}$; dextrose, $40 \mathrm{~g}$; water $200 \mathrm{ml}$ ). Another 10 subjects with biopsy-proven liver disease (Table 3) (one of whom was also a member of the first group) were studied twice-in the fasting state and, on another day, two hours after the oral ingestion of $2.5 \mathrm{~g}$ of nonradioactive cholylglycine (Weddell Pharmaceuticals, London) in gelatine capsules. The latter studies were termed 'loaded' tests. In each group half the subjects underwent the fasting study second in order. Subjects were semi-recumbent during the tests. All subjects gave informed consent to the investigation.

Cholyl- ${ }^{14} \mathrm{C}$-glycine (Radiochemical Centre, Amersham, Bucks.) was dissolved in saline and sterilised by filtration. Ten $\mu \mathrm{Ci}$ in $0.19 \mu \mathrm{mol}$ were given intravenously for each test. Venous blood was taken from an indwelling catheter in the opposite arm before and $2,4,6,9,12,15,20,30,40,50$, and 60 minutes after injection. Duplicate $1 \mathrm{ml}$ aliquots of 
Table 1 Control subjects—clinical details and kinetics of cholylglycine- ${ }^{14} \mathrm{C}$ disappearance

\begin{tabular}{|c|c|c|c|c|c|c|}
\hline \multirow{2}{*}{$\begin{array}{c}\text { Age } \\
(y r)\end{array}$} & \multirow{2}{*}{ Sex } & \multirow{2}{*}{ Diagnosis } & \multicolumn{2}{|c|}{ Clearance $\left(\mathrm{ml} . \mathrm{min}^{-1}\right)$} & \multicolumn{2}{|l|}{$T \frac{1}{2} \beta(\min )$} \\
\hline & & & Fasting & Postprandial & Fasting & Postprandial \\
\hline $\begin{array}{l}44 \\
57 \\
68 \\
69 \\
61 \\
47 \\
46\end{array}$ & $\begin{array}{l}\mathbf{F} \\
\mathbf{F} \\
\mathbf{M} \\
\mathbf{F} \\
\mathbf{M} \\
\mathbf{F} \\
\mathbf{M}\end{array}$ & $\begin{array}{l}\text { Irritable bowel } \\
\text { Deep venous thrombosis } \\
\text { Sinus bradycardia } \\
\text { Osteoarthrosis of spine } \\
\text { Pulmonary infarct } \\
\text { Psychogenic vomiting } \\
\text { Gilbert's syndrome (liver biopsy } \\
\text { normal) }\end{array}$ & $\begin{array}{l}586 \\
712 \\
491 \\
396 \\
857 \\
408 \\
994\end{array}$ & $\begin{array}{l}771 \\
707 \\
502 \\
416 \\
824 \\
519 \\
727\end{array}$ & \begin{tabular}{r|}
$8 \cdot 5$ \\
$15 \cdot 0$ \\
22.0 \\
$18 \cdot 3$ \\
$14 \cdot 8$ \\
$17 \cdot 7$ \\
$16 \cdot 2$
\end{tabular} & \begin{tabular}{r|}
$8 \cdot 6$ \\
$21 \cdot 2$ \\
$21 \cdot 6$ \\
$22 \cdot 6$ \\
$7 \cdot 6$ \\
$14 \cdot 3$ \\
$19 \cdot 1$
\end{tabular} \\
\hline \multicolumn{3}{|r|}{ 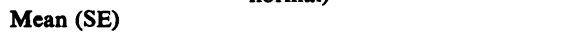 } & $635(87)$ & $638(59)$ & $16 \cdot 1(1 \cdot 5)$ & $16 \cdot 4(2 \cdot 4)$ \\
\hline
\end{tabular}

$T \mathfrak{z} \beta$ half-time for slow phase of disappearance curve.

Table 2 Clinical details and kinetics of cholylglycine- ${ }^{14} \mathrm{C}$ disappearance of 10 liver disease patients studied fasting and post-prandially

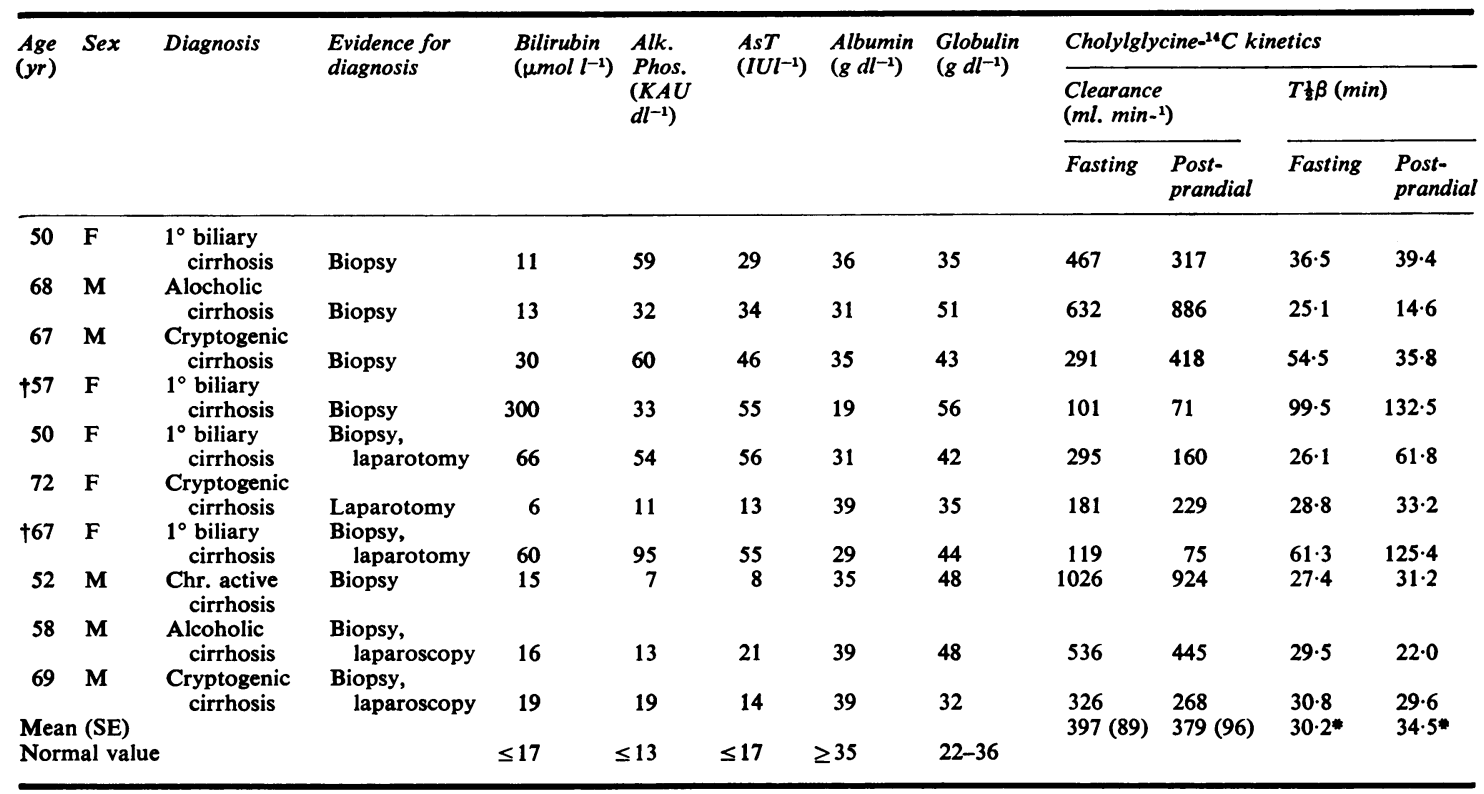

- Median. †Died. $T \frac{1}{2} \beta$ half-time for slow phase of disappearance curve.

plasma from each sample were equilibrated with $10 \mathrm{ml} \mathrm{NE}-260$ micellar scintillation fluid (Nuclear Enterprises, Edinburgh, Scotland) and counted in a liquid scintillation counter. Jaundiced sera were diluted if necessary to reduce quenching. Radioactivity was plotted against time giving a biexponential decay curve which was fitted by computer to the equation $y=a e^{-\alpha t}+b e^{-\beta t}$, where $y$ is serum concentration, $a$ and $b$ are constants, $\alpha$ and $\beta$ are the rate constants for the rapid and slow exponentials, and $t$ is time in minutes.

Bile acid clearance was calculated from the formula

$$
\mathrm{C}=\frac{\text { Dose }}{\mathrm{a} / \boldsymbol{\alpha}+\mathrm{b} / \boldsymbol{\beta}}
$$

The computer-derived half-time for the slow phase of the disappearance curve $\left(T^{\frac{1}{2}} \beta\right)$ was used as another measure of bile acid removal from the plasma. The fast phase was not used because it is not affected by liver disease (Gilmore and Thompson, 1978b).

Statistical significance of differences was calculated using student's $t$ test or the Wilcoxon rank sum test as appropriate for normally or non-normally distributed data.

\section{Results}

In the controls (Table 1) bile acid clearance and $T \frac{1}{2} \beta$ were closely similar in the fasting and postprandial states. Clearance was $635 \pm 87$ (mean \pm SEM) and 
Table 3 Clinical details and kinetics of cholylglycine-C $C^{14}$ disappearance of liver disease patients studied with and without bile acid load

\begin{tabular}{|c|c|c|c|c|c|c|c|c|c|c|c|c|}
\hline \multirow{3}{*}{$\begin{array}{l}\text { Age } \\
\text { (yr) }\end{array}$} & \multirow[t]{3}{*}{$\operatorname{Sex}$} & \multirow[t]{3}{*}{ Diagnosis } & \multirow{3}{*}{$\begin{array}{l}\text { Evidence for } \\
\text { diagnosis }\end{array}$} & \multirow{3}{*}{$\begin{array}{l}\text { Bilirubin } \\
\left(\mu \mathrm{mol} l^{-1}\right)\end{array}$} & \multirow{3}{*}{$\begin{array}{l}\text { Alk. } \\
\text { Phos. } \\
(K A U \\
\left.d l^{-1}\right)\end{array}$} & \multirow{3}{*}{$\begin{array}{l}A s T \\
\left(I U l^{-1}\right)\end{array}$} & \multirow{3}{*}{$\begin{array}{l}\text { Albumin } \\
\left(g d l^{-1}\right)\end{array}$} & \multirow{3}{*}{$\begin{array}{l}\text { Globulin } \\
\left(g d l^{-1}\right)\end{array}$} & \multicolumn{4}{|c|}{ Cholylglycine- ${ }^{14} C$ kinetics } \\
\hline & & & & & & & & & \multicolumn{2}{|l|}{$\begin{array}{l}\text { Clearance } \\
\left(m l . m^{-1}\right)\end{array}$} & \multicolumn{2}{|l|}{$\begin{array}{l}T \frac{1}{2} \beta \\
(\min )\end{array}$} \\
\hline & & & & & & & & & Fasting & $\begin{array}{l}\text { After } \\
\text { load }\end{array}$ & Fasting & $\begin{array}{l}\text { After } \\
\text { load }\end{array}$ \\
\hline 63 & $\mathbf{F}$ & $\begin{array}{l}\text { Cryptogenic } \\
\text { cirrhosis }\end{array}$ & $\begin{array}{l}\text { Biopsy, } \\
\text { laparotomy }\end{array}$ & 12 & 32 & 13 & 33 & 39 & 432 & 426 & 20.0 & $24 \cdot 1$ \\
\hline 41 & $\mathbf{F}$ & $\begin{array}{l}\text { Chr. active } \\
\text { cirrhosis }\end{array}$ & $\begin{array}{l}\text { Biopsy, } \\
\text { laparotomy }\end{array}$ & 18 & 22 & 28 & 39 & 41 & 316 & 442 & $43 \cdot 2$ & $21 \cdot 4$ \\
\hline 65 & $\mathbf{M}$ & $\begin{array}{l}\text { Alcoholic } \\
\text { cirrhosis }\end{array}$ & $\begin{array}{l}\text { Biopsy, } \\
\text { laparoscopy }\end{array}$ & 19 & 17 & 10 & 35 & 38 & 747 & 673 & $22 \cdot 1$ & $18 \cdot 7$ \\
\hline 58 & $\mathbf{M}$ & $\begin{array}{l}\text { Alcoholic } \\
\text { cirrhosis }\end{array}$ & $\begin{array}{l}\text { Biopsy, } \\
\text { laparoscopy }\end{array}$ & 16 & 13 & 21 & 39 & 48 & 553 & 679 & 20.0 & $18 \cdot 6$ \\
\hline 67 & $\mathbf{M}$ & $\begin{array}{l}\text { Cryptogenic } \\
\text { cirrhosis }\end{array}$ & Biopsy & 36 & 24 & 9 & 46 & 31 & 1249 & 823 & $29 \cdot 5$ & $16 \cdot 6$ \\
\hline 57 & $\mathbf{M}$ & $\begin{array}{l}\text { Alcoholic } \\
\text { hepatitis }\end{array}$ & Biopsy & 12 & 16 & 16 & 26 & 40 & 779 & 754 & $42 \cdot 1$ & $16 \cdot 7$ \\
\hline 64 & $\mathbf{F}$ & $\begin{array}{l}\text { Post-hepatitic } \\
\text { cirrhosis }\end{array}$ & $\begin{array}{l}\text { Biopsy, } \\
\text { laparotomy }\end{array}$ & 27 & 13 & 30 & 26 & 26 & 392 & 378 & $15 \cdot 2$ & $19 \cdot 4$ \\
\hline 60 & $\mathbf{F}$ & $\begin{array}{l}\text { Cryptogenic } \\
\text { cirrhosis }\end{array}$ & $\begin{array}{l}\text { Biopsy, } \\
\text { laparotomy }\end{array}$ & 64 & 51 & 90 & 29 & 48 & 90 & 79 & $80 \cdot 5$ & $91 \cdot 1$ \\
\hline 39 & $\mathbf{F}$ & $\begin{array}{l}\text { Alcoholic } \\
\text { cirrhosis } \\
\text { Cryptogenic }\end{array}$ & Biopsy & 33 & 9 & 21 & 33 & 50 & 328 & 230 & $31 \cdot 7$ & $42 \cdot 3$ \\
\hline Mean & (SE) & $\begin{array}{l}\text { cirrhosis } \\
\text { cirstogente }\end{array}$ & Biopsy & 49 & 37 & 92 & 30 & 36 & $\begin{array}{l}214 \\
510(107)\end{array}$ & $\begin{array}{l}128 \\
461(83)\end{array}$ & $\begin{array}{l}40 \cdot 4 \\
30 \cdot 6^{*}\end{array}$ & $\begin{array}{l}67 \cdot 4 \\
20 \cdot 4 *\end{array}$ \\
\hline Norm & nal value & & & $\leq 17$ & $\leq 13$ & $\leq 17$ & $\geq 35$ & $22-36$ & & & & \\
\hline
\end{tabular}

Median. $\quad T_{\frac{1}{2}}^{1} \beta$ half-time for slow phase of disappearance curve.

$638 \pm 59 \mathrm{ml} \mathrm{min}^{-1}$, respectively, while $\mathrm{T} \frac{1}{2} \beta$ was $16 \cdot 1 \pm$ $1 \cdot 5$ and $16 \cdot 4 \pm 2.4$ minutes, respectively.

In the liver disease patients bile acid clearance varied over a wide range in both the fasting and postprandial states (Table 2) and, by the paired $t$ test, there was no significant difference between the two sets of values (mean $397 \pm 89$ and $379 \pm 96 \mathrm{ml} \mathrm{min}^{-1}$, respectively). With $T \frac{1}{2} \beta$ the fasting and postprandial values were again not significantly different (median 30.2 and 34.5 minutes, respectively; paired Wilcoxon test NS). The two patients who died from their liver disease, and who also had the lowest clearance and the highest $T_{\frac{1}{2}} \beta$ values, both showed a fall in clearance and a rise in $T \frac{1}{2} \beta$ after the meal.

In the liver disease patients who were studied after a bile acid load (Table 3), cholylglycine clearance was similar in the fasting and loaded states-namely, $510 \pm 107$ and $461 \pm 83 \mathrm{ml} \mathrm{min}^{-1}$, respectively (paired $t$ test NS). There was also no difference in $\mathrm{T} \frac{1}{2} \beta$ (median 30.6 and 20.4 minutes, respectively; paired Wilcoxon test NS). The two patients who had the lowest clearance values in the fasting state both showed a rise in clearance after the load.

Pooling all 20 fasting studies in the liver disease patients gave a wide scatter of clearance values from 90 to $1249 \mathrm{ml} \mathrm{min}^{-1}$ (mean $454 \pm 69$ ). Overall, fasting clearance was not significantly different from that in the seven control subjects (unpaired $t$ test
$0.05<\mathrm{P}<0 \cdot 10$ ), though 11 of the patients had values below the lowest of the controls. In the 10 patients who were studied postprandially clearance was significantly less than in the controls studied postprandially (unpaired $t$ test $\mathbf{P}<0.02$ ). However, there was considerable overlap. $T \frac{1}{2} \beta$ was significantly prolonged in the liver disease patients compared with the controls, both in the fasting state and postprandially (both $P<0.01$ by Wilcoxon test), but in each case there was again considerable overlap.

\section{Discussion}

The finding that subjects with healthy livers showed no deterioration of bile acid clearance and $T \frac{1}{2} \beta$ after a meal was expected in view of the large reserve capacity of the normal liver and agrees with the report of LaRusso et al. (1978). However, there was also no postprandial deterioration in patients with proven chronic liver disease, except in the two patients with the most severe disease. This confirms the preliminary findings of Thjodleifsson et al. (1977), who even found a slight improvement in clearance after a meal in their four patients. It suggests that, except in advanced cirrhosis, the liver has considerable reserve capacity for uptake of bile acids. It also implies that the discriminating power of the bile acid disappearance test is not likely to be improved if the test is performed after a meal. 
It can normally be assumed that eating a meal markedly increases the amount of bile acids in circulation by causing the expulsion of concentrated bile from the gallbladder. This assumption cannot safely be made in cirrhotic patients, as they are known to have a high frequency of gallstones (Bouchier, 1969; Nicholas et al., 1972) and poor gallbladder contractility (Turnberg and Grahame, 1970). On ethical and practical grounds it was impossible to obtain radiographic data on all the controls and cirrhotic patients studied and three patients were known to have undergone cholecystectomy. It is possible, therefore, that in some patients bile acid kinetics failed to change postprandially partly because there was an impaired or absent gallbladder response to the meal. In this case, a change should have been obtained in the 'loaded' study, which was designed reliably to increase the amount of bile acid absorbed. No such change occurred, except in the two most severely ill patients.

Taken together, these findings imply that the postprandial rise in serum bile acid concentrations which is generally said to occur even in mild liver disease is not due to hepatic overload. The present study does not point specifically to the responsible mechanism but a plausible theory (Kaye et al., 1973) blames it on portosystemic shunting, which after a meal operates on a greater amount of circulating bile acids. Alternatively, when splanchnic blood flow increases after a meal there could be an increased proportion of portal blood bypassing the liver. Consistent with this emphasis on the portal blood flow is a preliminary report that an oral tolerance test using cholic acid was more impaired in anicteric liver disease than its intravenous counterpart (Gilmore and Thompson, 1978a). It is certainly more logical to present a bile acid to the liver by the portal than the systemic route.

Not only does the intravenous bile acid tolerance test have theoretical shortcomings, but the present findings add to the evidence that it is of doubtful clinical value. Similarly, Gilmore and Thompson (1978b) have found intravenous cholylglycine- ${ }^{14} \mathrm{C}$ clearance to be often normal in mild liver disease.

We thank Professor A. E. Read for permission to study his patients and for his active encouragement. K.L. was supported by a grant from the Royal Australasian College of Physicians and Roche Products N.Z. Ltd.

\section{References}

Barnes, S., Gallo, G. A., Trash, D. B., and Morris, J. S. (1975). Diagnostic value of serum bile acid estimations in liver disease. Journal of Clinical Pathology, 28, 506509.
Bouchier, I. A. D. (1969). Postmortem study of the frequency of gallstones in patients with cirrhosis of the liver. Gut, 10, 705-710.

Calcraft, B., LaRusso, N. F., and Hofmann, A. F. (1975). Development of a simple, safe, bile acid clearance test : the radio-cholate clearance test (Abstract). Gastroenterology, 69, 812.

Fausa, O. (1976). Serum bile acid concentration after a test meal. Scandinavian Journal of Gastroenterology, 11, 229-232.

Fausa, O., and Gjone, F. (1976). Serum bile acid concentrations in patients with liver disease. Scandinavian Journal of Gastroenterology, 11, 537-543.

Ferguson, D. R., Calcraft, B. J., Hofmann, A. F., and Belobaba, D. T. A. (1976). Lack of sensitivity of a bile acid clearance test in the detection of liver disease (Abstract). Gastroenterology, 71, 905.

Gilmore, I. T., and Thompson, R. P. H. (1977). Plasma bile acid disappearance rate as a test of liver functiona critical reassessment (Abstract). Gut, 18, A402.

Gilmore, I. T., and Thompson, R. P. H. (1978a). Oral and intravenous cholic acid clearance and serum bile acids compared in the detection of chronic liver disease (Abstract). Gut, 19, A451-452.

Gilmore, I. T., and Thompson, R. P. H. (1978b). Kinetics of ${ }^{14} \mathrm{C}$-glycocholic acid clearance in normal man and in patients with liver disease. Gut, 19, 1110-1115.

Hofmann, A. F. (1977). The enterohepatic circulation of bile acids in man. Clinics in Gastroenterology, 6, 3-24.

Isaacs, P. E. T., Iser, J. H., Murphy, G. M., and Dowling, R. H. (1976). Serum bile acids (SBAs) and plasma bile acid disappearance (PBAD) as tests of liver function: a study in controls, patients with liver disease and gallstone patients before and after chenodeoxycholic acid (CDCA) treatment (Abstract). Gut, 17, 822.

Josephson, B. (1941). The circulation of the bile acids in connection with their production, conjugation and excretion. Physiological Reviews, 21, 463-486.

Kaplowitz, N., Kok, E., and Javitt, N. B. (1973). Postprandial serum bile acid for the detection of hepatobiliary disease. Journal of the American Medical Association, 225, 292-293.

Kaye, M. D., Struthers, J. E., Jr., Tidball, J.S., DeNiro, E., and Kern, F., Jr. (1973). Factors affecting plasma clearance of $\left[{ }^{14} \mathrm{C}\right]$ cholic acid in patients with cirrhosis. Clinical Science and Molecular Medicine, 45, 147-161.

LaRusso, N. F., Hoffman, N. E., Hofmann, A. F., and Korman, M. G. (1975). Validity and sensitivity of an intravenous bile acid tolerance test in patients with liver disease. New England Journal of Medicine, 292, 1209-1214.

LaRusso, N. F., Hoffman, N. E., Korman, M. G., Hofmann, A. F., and Cowen, A. E. (1978). Determinants of fasting and postprandial serum bile acid levels in healthy man. American Journal of Digestive Diseases, 23, 385-391.

Nicholas, P., Rinaudo, P. A., and Conn, H. O. (1972). Increased incidence of cholelithiasis in Laënnec's cirrhosis. A postmortem evaluation of pathogenesis. Gastroenterology, 63, 112-121.

Osuga, T., Mitamura, K., Mashige, F., and Imai, K. (1977). Evaluation of fluorimetrically estimated serum 
bile acid in liver disease. Clinica Chimica Acta, 75, 8190.

Pennington, C. R., Ross, P. E., and Bouchier, I. A. D. (1977). Serum bile acids in the diagnosis of hepatobiliary disease. Gut, 18, 903-908.

Schwarz, H. P., von Bergmann, K. P., and Paumgartner, G. (1974). A simple method for the estimation of bile acids in serum. Clinica Chimica Acta, 50, 197-206.

Thjodleifsson, B., Barnes, S., Chitranukroh, A., Billing,
B. H., and Sherlock, S. (1977). Assessment of the plasma disappearance of cholyl-1 ${ }^{14} \mathrm{C}$-glycine as a test of hepatocellular disease. Gut, 18, 697-702.

Turnberg, L. A., and Grahame, G. (1970). Bile salt secretion in cirrhosis of the liver. Gut, 11, 126-133.

van Blankenstein, M., v.d. Berg, J. W. O., Frenkel, M., and ten Kate, F. J. W. (1977). The endogenous bile acid tolerance test. Netherlands Journal of Medicine, 20, 235-236. 